\title{
Behavior of Incubating American Woodcock (Scolopax minor) in Maine
}

DANIEL G. MCAULEY, ${ }^{1}$ U.S. Geological Survey, Patuxent Wildlife Research Center, 17 Godfrey Drive, Suite 2, Orono, ME 04473 USA

DAVID A. CLUGSTON, ${ }^{2}$ U.S. Geological Survey, Patuxent Wildlife Research Center, 17 Godfrey Drive, Suite 2, Orono, ME 04473 USA

JERRY R. LONGCORE, ${ }^{2}$ U.S. Geological Survey, Patuxent Wildlife Research Center, 17 Godfrey Drive, Suite 2, Orono, ME 04473 USA

WILLIAM A. HALTEMAN, ${ }^{4}$ Department of Mathematics and Statistics, Neville Hall, University of Maine, Orono, Maine 04469 USA

\begin{abstract}
During April - June 1987 and 1988, we remotely monitored 14 radio-marked female American Woodcock (Scolopax minor; hereafter woodcock) at 18 nest sites on Moosehorn National Wildlife Refuge in Maine, U.S.A., to determine patterns and constancy of nest incubation behavior. On average, females spent $93 \%$ of their time on the nest and $7 \%$ off the nest, leaving nests for an average of 104.2 minutes during a 24 -hour period. Time off the nest each day did not vary by year, daily high temperature, or amount of daily precipitation. Our data suggest that renesting females spent more time off nest/day than females on first nests, and that second-year females made more diurnal recesses from the nest than aftersecond-year females. Most woodcock left the nest during crepuscular periods. Our results provide information about nest incubation constancy, and may be useful for informing woodcock research and habitat management.
\end{abstract}

Proceedings of the American Woodcock Symposium 11: 265-269

KEY WORDS: incubation constancy, nesting, Maine, renesting, recesses, Scolopax minor

The American Woodcock (Scolopax minor; hereafter woodcock) is a forest-dwelling shorebird and is probably one of the earliest ground-nesting species throughout its breeding distribution (Mendall and Aldous 1943, McAuley et al., 2013). In Maine, courtship begins in late March and nesting begins in early April, when temperatures can still drop below freezing and significant snowfall can occur (McAuley et al., 1990). Courtship and breeding in Maine last about 2.5 months (i.e., typically through mid-June; Mendall and Aldous 1943), with eggs hatching as late as 6 July (U.S. Geological Survey unpublished data). Nests usually are located in young, sparsely stocked upland

1 email: dmcauley@usgs.gov

2 retired; current address: P.O. Box 555, Lyle, WA 98635

3 retired; current address: 151 Bennoch Road, Orono, ME 04473

4 retired; current address: 143 Bennoch Road, Orono, ME 04473 hardwoods and mixed woodland cover types (McAuley et al., 2013). Gregg and Hale (1977) reported woodcock nests in stands of aspen (Populus spp.) and beaked hazel (Corylus cornuta) in Wisconsin. On actively managed sites (i.e., Moosehorn National Wildlife Refuge), woodcock select areas with low basal area and high stem density (McAuley et al., 1996).

Only the female woodcock, which is larger in body mass than the male, incubates eggs. Woodcock nests are little more than a shallow depression into which leaves and grass litter are incorporated (Mendall and Aldous 1943). The success of incubation depends on effective 
temporal organization of incubation effort that confronts unpredictable weather, snow, and low diurnal temperatures while balancing the female's need to feed (Norton 1972). Adult attentiveness is essential to maintain egg temperatures to prevent lethal chilling (Carey 1980); the energetic demands of incubation are thus particularly acute for single-sex incubators, such as woodcock, that must take recesses from the nest to feed. Although some Scolopacidae species share incubation between the sexes, single-sex incubating wading birds usually take short recesses. For example, pectoral sandpiper (Calidris melantos) take 8-15-minute recesses and white-rumped sandpiper (C. fusciollis) take 8-12-minute recesses off the nest alternating with longer periods of incubating eggs (Norton 1972, Wilkie 1981, Kondrat'ev 1982). Allocating time for foraging is necessary to obtain energy and still incubate efficiently (White and Kinney 1974, Vleck 1981). Pettingill (1936), Mendall and Aldous (1943), and Sheldon (1967) generally describe female woodcock leaving nests at dawn and dusk to feed; little else is reported about incubation behavior. Likewise, McAuley et al. (1993a) reported that females usually leave the nest at dawn and dusk to visit displaying males and to feed, but activities and behaviors during the rest of the day are unknown. Because of the lack of information about incubation behavior, we documented activity budgets of incubating female woodcock. As such, our main objective was to describe various aspects of woodcock incubation behavior, including incubation constancy, frequency of recesses, and recess duration.

\section{STUDY AREA}

We marked woodcock at Moosehorn National Wildlife Refuge (NWR), which is comprised of 6,580 ha and located in eastern Maine, Washington County, near Calais on the United States-Canada border. Much of the refuge was clearcut and burned by a wildfire around the turn of the 2oth century (Sepik et al., 1986). Many farms that were economically tied to the forestry industry were abandoned as timber supply declined in the early 1900 s and became part of the refuge. By 1975, most of the refuge was covered by mature second-growth forest interspersed with natural and impounded water bodies, several meadows, and managed blueberry (Vaccinium spp.) fields. The forest was composed of pure stands of spruce (Picea spp.) and balsam fir (Abies balsamea) that were heavily damaged by spruce budworm (Choristoneura fumiferana) infestation (Dwyer et al.1988). Hardwood stands dominated by birch (Betula spp.), red maple (Acer rubrum), and aspen (Populus spp.) were common, but were gradually being replaced by conifers. Alder (Alnus spp.) stands were common along streams and in some abandoned fields. An active timber-cutting program to encourage woodcock habitat development was established in 1978 whereby $40-60$ ha of mature timber were harvested annually (Sepik and Dwyer 1982).

\section{METHODS}

\section{CAPTURE AND MONITORING FEMALE WOODCOCK}

We used mist nets (Sheldon 1967) in the evening from 26 March to 30 May in 1987-1988 to capture female woodcock visiting display sites of males (McAuley et.al. 1993b). In addition, we used a trained dog (Ammann 1974, 1977; McAuley et al., 1993b) to capture some females with broods. We placed U.S. Fish and Wildlife Service aluminum leg bands on each woodcock, and determined age (SY, second-year. [1-yr-old]) and ASY, after-second-yr. [> 2 yr. old]) based on plumage characteristics (Martin 1964). We determined sex by measuring the combined width (at the widest part) of the outer 3 primaries (Greeley 1953) and length of the bill (Mendall and Aldous 1943).

We used cattle tag cement (Hudgins et al., 1985) to glue a VHF radio transmitter weighing $3-4 \mathrm{~g}(<3 \%$ of body mass) to the back of each woodcock. We positioned a single loop of Teflon-coated steel wire $\left(\right.$ Berkley $\left.{ }^{\circ}\right)$, embedded in the transmitter (Hudgins et al., 1985), around the breast and threaded the ends of the wires through a connector sleeve, crimped the sleeve, and trimmed excess wire (McAuley et al., 1993b).

We monitored females attending nests with a shielded coaxial cable from which we had removed a $3.8-\mathrm{cm}$ section of coating to expose the inner wire that we then placed $30 \mathrm{~cm}$ above the nest. The cable extended to a hidden receiver (Licht et al., 1989) placed $\sim 15 \mathrm{~m}$ from the nest, and we used a Rustrak (ISE, Inc.) recorder to monitor the presence, absence, and activity of birds within $\sim 10 \mathrm{~m}$ of the nest (see Licht et al., 1989 for details). Rustrak recorders use tape to record whether telemetry signals are detected, and we changed the tape on the recorder daily. We used data recorded on the tapes to determine the amount of time that females were on and off the nest during different daily periods (crepuscular, diurnal, and nocturnal) and whether they were active near the nest or left the immediate vicinity $(>10 \mathrm{~m})$ when off the nest.

\section{STATISTICAL ANALYSIS}

We calculated summary statistics for the variables we measured related to the time female woodcock were on and off the nest during 4 periods of a 24-hour day (crepuscular a.m., crepuscular p.m., diurnal, and nocturnal) and recorded the number of times they left the nest during the diurnal and nocturnal periods. We used weather-station data from Moosehorn NWR to evaluate the effects of daily high temperature, precipitation, and moon phase on the total time woodcock were off the nest per day. We also assessed differences by year (1987 vs 1988), age of females (second-year vs. after-second-year), and nest number (first nests vs. renests). We assumed that nests for females marked early in the breeding season (early April) were a first nest and we knew if they renested since they were marked. 
We analyzed data using a nested ANOVA design with nest identification (FREQ) nested within AGE, to account for the repeated, daily observations of our marked sample of female woodcock. We conducted all analyses with SAS ${ }^{\odot}$ software (SAS Institute Inc., Cary, NC, USA).

\section{RESULTS}

We monitored 14 (6 in 1987, 8 in 1988) radio-marked female woodcock at nest sites on Moosehorn NWR during April to June in 1987 and 1988. From our marked sample, we monitored 18 nests consisting of 12 initial nests and 6 renests. We collected nest time-budget data for 164 "nest days" ( 83 in 1987 and 81 in 1988) over the 2 breeding seasons.

On average, female woodcock spent $93 \%$ of the 24 -hour day on the nest and $7 \%$ of the time off the nest (Fig. 1). Nesting female woodcock left their nests during $98 \%$ of the crepuscular periods we monitored, and remained on the nest for only 5 of 164 morning and 3 of 164 evening crepuscular periods, respectively.

Incubating female woodcock were off the nest an average of $104.2 \mathrm{~min}(95 \% \mathrm{CI}=95.1-113.2)$ per day (Table 1$)$. We determined that, when off the nest, the female was active in the immediate vicinity $(<10.1 \mathrm{~m})$ of the nest $42 \%$ of the time and was farther away the remainder of the time.

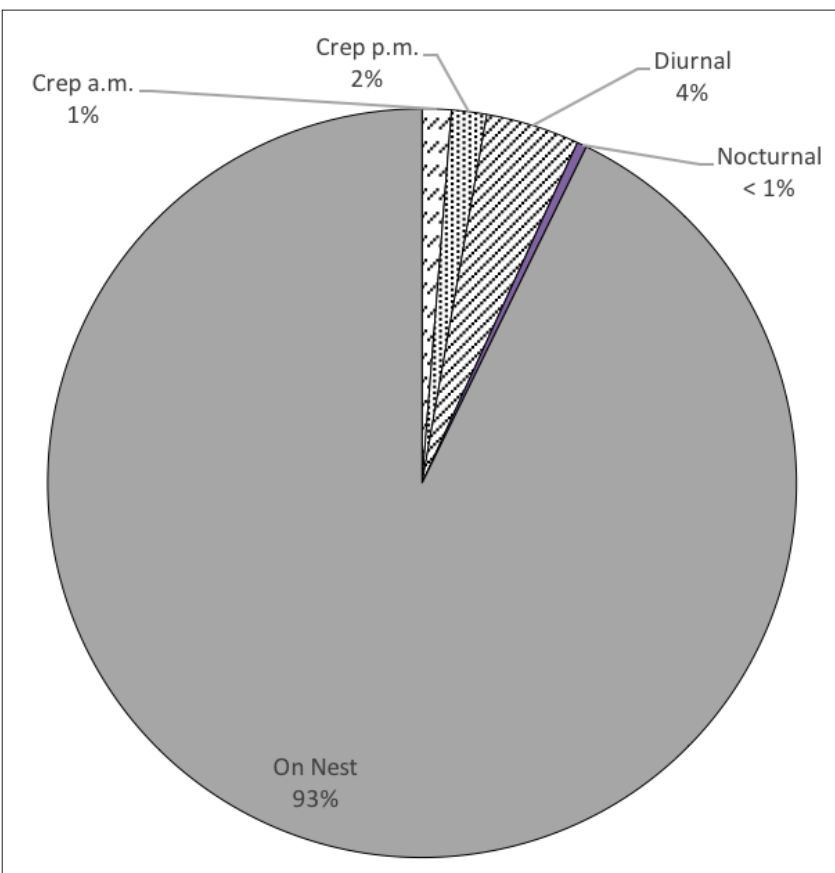

Figure 1. Average daily (24-hour) time budget (on nest vs. off nest) for incubating female America Woodcock $(\mathrm{n}=14)$ at Moosehorn NWR, Maine, U.S.A., during 1987-1988. Off nest time was divided into 4 daily periods: Crepuscular a.m. (Crep a.m.), Crepuscular p.m. (Crep p.m.), Diurnal, and Nocturnal.
Female woodcock spent the most time off the nest during daylight hours $(\bar{x}=58.2 \mathrm{~min}, 95 \% \mathrm{CI}=49.5-67.0$; Table 1$)$ and the least amount of time off the nest during the night $(\bar{x}=6.1 \min 95 \% \mathrm{CI}=2.6-9.5$; Table 1$)$. Time off the nest during morning $(\bar{x}=18.1 \mathrm{~min}, 95 \% \mathrm{CI}=16.7-19.4)$ and evening $(\bar{x}=21.8 \mathrm{~min}, 95 \% \mathrm{CI}=20.0-23.5)$ crepuscular periods was similar.

We determined that the total time off the nest each day did not vary by year $(D F=1,10, F=0.44, P=0.52)$, daily high temperature $(D F=1,10, F=0.06, P=0.79)$, or amount of daily precipitation $(D F=1,10, F=0.41, P=0.53)$. Moon phase had no effect on the number of recesses $(D F=3,17, F$ $=1.72, P=0.20$ ) during nocturnal periods. There was some evidence that renesting female woodcock spent more time off the nest during diurnal periods than female woodcock tending initial nests $(D F=1,2, F=9.65, P=0.090)$.

On average, incubating female woodcock made 2.24 $(95 \% \mathrm{CI}=2.1-2.7)$ recesses per day from the nest during diurnal periods (Table 2), whereas they rarely left nests at night (0.3 recesses per night, 95\% CI $=0.1-0.4)$. Second-year incubating females took more frequent diurnal recesses $(\bar{x}=3.1,95 \% \mathrm{CI}=2.8-3.4)$ than after-second-year females $(\bar{x}=1.9,95 \% \mathrm{CI}=1.7-2.1 ; D F=1,9, F=12.38, P=$ o.006). Two woodcock left their nest 6 times in 1 day and 5 left 5 times. One female woodcock remained away from the nest for 415 minutes and 191 minutes during 2 different diurnal periods. The longest off-nest interval at night was 88 minutes for a single female.

\section{DISCUSSION}

Our results represent the first data documenting the amount of time incubating female woodcock spend on and off the nest per day. Previously, Pettingill (1936), Mendall and Aldous (1943), and Sheldon (1967) generally described female woodcock leaving nests at dawn and dusk to feed; little else was reported about incubating behavior. Likewise, McAuley et al., (1993a) reported that females usually leave the nest at dawn and dusk to visit displaying males and to feed, but activities and behaviors during the rest of the day are unknown. Whereas females consistently left the nest during crepuscular periods as previously described, we also found they made frequent recesses during the diurnal period each day, and we were able to document the number and lengths of these recesses (Table 1).

Woodcock incubation patterns (93\% incubation constancy, Fig. 1) were similar to those of other single-parent incubating birds. Incubation constancy has been reported as $95 \%$ for the female capercallie (Tetrao urogallus) (Lennerstedt 1966), 95\% for white-tailed ptarmigan (Lagopus leucurus) (Giesen and Braun 1979), 93\% for spruce grouse (Canachites Canadensis) (McCourt et al.1973), and 96\% for ruffed grouse (Bonasa umbellus) (Maxson 1977). Some species, such as female white-tailed ptarmigan and blue 
Table 1. Mean time (minutes) and 95\% confidence intervals (CI) spent off the nest per day by period of the day for female American Woodcock at Moosehorn NWR, Maine U.S.A., 1987-1988.

\begin{tabular}{|c|c|c|c|c|c|c|}
\hline \multicolumn{7}{|c|}{ Crepuscular } \\
\hline Year & $\begin{array}{c}\text { a.m. } \\
( \pm 95 \% \mathrm{CI})\end{array}$ & $\begin{array}{c}\text { p.m. } \\
( \pm 95 \% \mathrm{CI})\end{array}$ & $\begin{array}{c}\text { Diurnal } \\
( \pm 95 \% \mathrm{CI})\end{array}$ & $\begin{array}{l}\text { Nocturnal } \\
( \pm 95 \% \mathrm{CI})\end{array}$ & $\begin{array}{c}\text { Total off nest } \\
( \pm 95 \% \mathrm{CI})\end{array}$ & $\begin{array}{c}\text { Prop. } \\
\text { off }^{c}\end{array}$ \\
\hline $1987(n=6)^{\mathrm{a}}$ & $16.5(15.2-17.8)$ & $20.7(18.8-22.7)$ & $55.1(49.8-60.4)$ & $6.3(2.2-10.4)$ & $98.7(92.2-105.2)$ & 0.07 \\
\hline $1988(n=8)^{\mathrm{b}}$ & $19.7(18.4-21.1)$ & $22.8(21.3-24.4)$ & $61.4(50.0-72.8)$ & $5.8(3.1-8.5)$ & $109.8(98.7-120.8)$ & 0.08 \\
\hline Combined & $18.1(16.7-19.4)$ & $21.8(20.0-23.5)$ & $58.2(49.5-67.0)$ & $6.1(2.6-9.5)$ & $104.2(95.1-113.2)$ & 0.07 \\
\hline $\begin{array}{l}\text { a } \text { Six female woc } \\
\text { b Eight female w } \\
\text { c Proportion wa }\end{array}$ & $\begin{array}{l}\text { ck were monitored } \mathrm{f} \\
\text { cock were monitore } \\
\text { culated by dividing }\end{array}$ & $\begin{array}{l}r \text { a total of } 83 \text { days in } 1 \\
\text { for a total of } 81 \text { days ir } \\
\text { ne total time off the ne }\end{array}$ & $\begin{array}{l}87 . \\
1988 . \\
\text { by } 1,440 \text { (minutes in }\end{array}$ & 4-hour day). & & \\
\hline
\end{tabular}

grouse (Dendragapus obscurus), are reluctant to leave their nests (they can often be touched on the nest when in the late stages of incubation) and have high levels of nest attendance (Giesen and Braun 1979, Zwickel and Bendell 2005). Although woodcock may desert a nest when disturbed early in the incubation period, as incubation progresses they are less likely to abandon the nest and can be handled without subsequent nest abandonment (McAuley et al., 2013).

During our study, females left their nests during 98\% of crepuscular periods, whereas McAuley et al., (1993a) reported that in $82 \%$ of 302 movements radio-marked females at Moosehorn NWR left their nest during crepuscular periods. McAuley et al., (1993a) documented that, during these evening and morning recesses, $58 \%$ of females sought food, but $7 \%$ of females visited courting males before going to feed, $7 \%$ went to unidentified locations, and $28 \%$ did not leave their nest. During crepuscular recesses, we suspect that females were visiting males first and then feeding. This pattern differs from those of most other shorebirds, but the courtship pattern of male woodcock likely influences the nest recesses during crepuscular periods of the day.

Female woodcock left their nests for the longest periods during daylight hours $(\bar{x}=58.2 \mathrm{~min}$, Table 1$)$ and averaged 2.4 recesses during that period. In contrast, a single S. rusticola (European Woodcock) took 4 recesses per day averaging 31.1 minutes/recess for 124 minutes off the nest during the day (Forges 1975). This is similar to 3 species of incubating sandpipers; dunlin (Calidris alpine) averaged 97.5 minutes, Baird's sandpiper (C. bairidii) averaged 96.5 minutes, and pectoral sandpiper (C. melanotos) averaged 85.0 minutes (Norton 1972). For the first 2 species, both sexes incubate, but for pectoral sandpiper only the females incubate.

High nest attentiveness may be an adaptive behavior to provide cover for exposed eggs in nests constructed with minimal nest material, thereby reducing detection of eggs by visual predators (Westmoreland and Best 1986). Fur-
Table 2. Number of recesses from the nest for American Woodcock during diurnal and nocturnal periods at Moosehorn NWR, Maine, U.S.A., 1987-1988.

\begin{tabular}{lcc}
\hline Year & $\begin{array}{c}\text { Diurnal recesses } \\
( \pm \mathbf{9 5 \%} \text { CI })\end{array}$ & $\begin{array}{c}\text { Nocturnal recesses } \\
( \pm \mathbf{9 5 \%} \text { CI })\end{array}$ \\
\hline $1987(n=6)^{\mathrm{a}}$ & $2.8(2.5-3.1)$ & $0.2(0.1-0.3)$ \\
$1988(n=8)^{\mathrm{b}}$ & $2.0(1.8-2.3)$ & $0.3(0.2-0.5)$ \\
Combined & $2.4(2.1-2.7)$ & $0.3(0.1-0.4)$ \\
\hline a $\quad$ Six female woodcock were monitored for a total of 83 days in 1987. \\
b $\quad$ Eight female woodcock were monitored for a total of 81 days in 1988. \\
\hline
\end{tabular}

thermore, high nest attendance is probably necessary to maintain the proper thermal environment for developing embryos (Deeming 2002). Because woodcock have completely exposed eggs (i.e., they do not pluck down to cover the eggs), high constancy is required to maintain incubation temperature, especially because they nest early in the season when ambient temperatures can be below freezing. Female woodcock are at their lowest mass of the year when their broods hatch (179.7 g SD $9.2[n=69]$; unpublished data), which is likely a consequence high nest attentiveness. Nesting and pre-nesting female woodcock from Moosehorn NWR weighed an average of $226.4 \mathrm{~g}$ (SD = $16.3[n=17]$, unpublished data). These values are similar to data from Minnesota, where female woodcock weighed an average of about $230 \mathrm{~g}$ pre-nesting and $180 \mathrm{~g}$ when with broods (Marshall 1982).

We noted that second-year females were off the nest more times than after-second-year females, which may be a function of inexperience or being in poorer condition, although the difference only amounted to an average of 1 more time off the nest per day. We expected that moon phase would influence the amount of time female woodcock were off the nest at night because males display at night when the moon is visible, and as such, we expected females would visit males more often during this period. 
However, we found no effect of moon phase on nest attentiveness.

Our study represents the first detailed information about woodcock incubation behavior. Future research should look at relationships between nest success and incubation behavior while considering landscape variables. Better understanding of these relationships may improve management of woodcock habitat, perhaps by encouraging the provision of high-quality feeding cover near nesting cover. Such juxtaposition of nesting and feeding cover may result in females making fewer or shorter recesses to feed, thereby decreasing exposure risk to predation or allowing incubation that is more constant.

\section{ACKNOWLEDGMENTS}

We thank D. S. Licht for developing the monitoring system. D. G. Krementz, T. R. Cooper, and D. R. Dessecker reviewed early drafts of the manuscript. Any use of trade, product or firm names is for descriptive purposes only and does not imply endorsement by the U.S. Government.

\section{LITERATURE CITED}

Ammann, G.A. 1974. Methods of capturing American Woodcock broods. Pages 593-605 in Eleventh International Congress of Game Biologists. S. Lundstrom, editor. National Swedish Environmental Board, Stockholm, Sweden

Ammann, G.A. 1977. Finding and banding woodcock broods using pointing dogs. Michigan Department of Natural Resources, Wildlife Division Report 2780, Lansing, MI, USA.

Carey, C. 1980. The ecology of avian incubation. Bioscience 30:819-824.

Deeming, D.C. 2002. Behavior patterns during incubation. Pages 63-87 in Avian incubation: behavior, environment and evolution. D. C. Deeming, editor. Oxford University Press, Oxford, UK.

Dwyer, T.J., G.F. Sepik, E.L. Derleth, and D.G. McAuley. 1988. Demographic Characteristics of a Maine Woodcock population and effects of habitat management. U.S. Fish and Wildlife Service, Fish and Wildlife Research 4, Washington, D.C., USA.

Forges, G. des. 1975. Behaviour of incubating woodcock. British Birds. 68:421-428.

Giesen, K.M., and C.E. Braun. 1979. Nesting behavior of female White-tailed Ptarmigan in Colorado. Condor 81:215-217.

Greeley, F. 1953. Sex and age studies in fall-shot woodcock (Philohela minor) from southern Wisconsin. Journal of Wildlife Management 17:29-32.

Gregg, L.E., and J.B. Hale. 1977. Woodcock nesting habitat in northern Wisconsin. Auk 94:489-493.

Hudgins, J.E., G.L. Storm, and J.S. Wakely. 1985. Local movements and diurnal habitat selection by male American Woodcock in Pennsylvania. Journal of Wildlife Management 49:614-619.

Kondrat'ev, A.J. 1982. Biologija kulikov v tundrach Severo-Vostoka Azil, A.N.SSSR.-Mosk. 192 pp. (In Russian).

Lennerstedt, I. 1966. Egg temperature and incubation rhythm of a Capercallie (Tetrao urogallus L.) in Swedish Lapland. Oikos 17:169-174.

Licht, D.S., D.G. McAuley, J.R. Longcore, and G.F. Sepik. 1989. An improved method to monitor nest attentiveness using radio-telemetry. Journal of Field Ornithology 60:251-258.

Marshall, W.H. 1982. Minnesota woodcock. The Loon 54:203-211.

Martin, F.W. 1964. Woodcock age and sex determination from wings. Journal of Wildlife Management 28:287-293.
Maxson, S. J. 1977. Activity patterns of female Ruffed Grouse during the breeding season. Wilson Bulletin 89:439-455.

McAuley, D.G., D.M. Keppie and R M.Whiting, Jr. 2013. American Woodcock (Scolopax minor). The birds of North America online (A. Poole, ed.). Cornell Lab of Ornithology <http://bna.birds. cornell.edu/bna/species/10o> (July 9, 2013).

McAuley, D.G., J.L. Longcore, G.F. Sepik, and G.W. Pendleton. 1996. Habitat characteristics of American Woodcock nests sites on a managed area in Maine. Journal of Wildlife Management 601:138-148.

McAuley, D.G., J.L. Longcore, and G.F. Sepik. 1993a. Behavior of radio-marked breeding American Woodcock. Pages 116-125 in Proceedings of the Eighth American Woodcock symposium. J. R. Longcore and G. F. Sepik, Editors. Fish and Wildlife Service biological report 16. U. S. Department of the Interior, Fish and Wildlife Service, Washington, D.C., USA

McAuley, D.G., J.L. Longcore, and G.F. Sepik. 1993b. Techniques for research into Woodcocks: experiences and recommendations. Pages 5-11 in Proceedings of the Eighth American Woodcock symposium. J. R. Longcore and G. F. Sepik, Editors. Fish and Wildlife Service biological report 16. U. S. Department of the Interior, Fish and Wildlife Service, Washington, D.C., USA

McAuley, D.G., J.L. Longcore, and G.F. Sepik. 199o. Renesting by American Woodcocks (Scolopax minor) in Maine. Auk 107:407-410.

Mccourt, K.H., D.A. Boag, and D.M. Keppie. 1973. Female Spruce Grouse activities during laying and incubation. Auk 90:619-623.

Mendall, H. L. and C.M Aldous. 1943. The ecology and management of the American Woodcock. Maine Cooperative Wildlife Research Unit, Orono, ME, USA.

Norton, D.W. 1972. Incubation schedules of four species of Calidridine sandpipers at Barrow, Alaska. Condor 74:164-176.

Pettingill, O.S., Jr. 1936. The American Woodcock Philohela minor (Gmelin). Memoirs of the Boston Society of Natural History 9:169-391.

Sepik, G.F., D. Mullen, T.J. Dwyer, E.L. Derleth, and D.G. McAuley. 1986. Forest-Wildlife management on the Moosehorn National Wildlife Refuge. in (J. A Bissonette, ed): Is good forestry good wildlife management? Pp. 333-339 Publication No 689. ME Agricultural Experiment Station, University of Maine.

Sepik, G.F. and T.J. D. 1982. Woodcock response to habitat management in Maine. Pages 106-113 in Woodcock ecology and management. T .J. Dwyer and G. L. Storm, technical coordinators. U.S. Fish and Wildlife Service Wildlife Research Report 14. Washington, D.C., USA

Sheldon, W.G. 1967. The book of the American Woodcock. University of Massachusetts Press, Amherst, MA. USA.

Vleck, C.M. 1981. Hummingbird incubation: female attentiveness and egg temperature. Oecologia 51:199-205.

Westmoreland, D. and L.B. Best. 1986. Incubation continuity and the advantage of cryptic egg coloration in Mourning Doves. Wilson Bulletin 98:297-300.

White, F.N. and J.L Kinney. 1974. Avian incubation. Science 186:107-112.

Wilkie, A.O.M. 1981. Incubation rhythm and behavior of a Dotterel Charadrius morinellus nesting in Norway. Ornis Fennica 58:11-20.

Zwickel, F.C. and J.F. Bendell. 2005. Blue Grouse (Dendragapus obscurus) The Birds of North America Online (A. Poole, ed.). Cornell Lab of Ornithology Ithaca. http://bna.birds.cornell.edu/ bna/species/15 (November 1, 2005). 